\title{
Outer Mongolia and the Changing Dynamics of UN Representation: Impacts on U.S. China Policy, 1961
}

\author{
JEAN S. KANG
}

In 1961, the Kennedy administration confronted widespread domestic and foreign anticipation that significant changes would be made to existing U.S. China policy. Although the new administration proposed to liberate the United States from past policies and offer fresh, innovative solutions to problems confronted worldwide, the major issues that characterized and defined the American relationship with both the Chinese Communists on the mainland and the Chinese Nationalists on Taiwan posed a challenge for the new President and his top advisers. This study examines the Kennedy administration's deliberations at the United Nations with regard to the Outer Mongolian representation matter and mounting international pressures from U.S. allies and other nations for the United States to assume a more flexible posture toward Communist China. Despite the lack of a major departure from existing policies, initiatives proposing a reappraisal of U.S. China policy during the Kennedy administration precipitated discussions and debates that contributed significantly to the eventual transformation of Sino-American relations.

Keywords: Outer Mongolia, UN representation, U.S.-China Relations, China-African Relations, U.S. Northeast Asia Policy

*Associate Professor, Ewha Womans University; E-mail: jskang@ewha.ac.kr 


\section{INTRODUCTION}

In 1961, the administration of John F. Kennedy confronted widespread domestic and foreign anticipation that significant changes would be made to existing U.S. China policy. Although the new administration proposed to liberate the United States from past policies and offer fresh, innovative solutions to problems confronted worldwide, the major issues that characterized and defined the American relationship with both the Chinese Communists on the mainland and the Chinese Nationalists on Taiwan posed a challenge for the new President and his foreign policy advisers.

Several contending circumstances offered the opportunity for the Kennedy administration to establish a new direction in U.S. China policy: the Chinese representation issue at the United Nations and related debates with the GRC (Government of the Republic of China) on alternative strategies; the U.S. position regarding the Nationalist regime's efforts to return to the mainland and to negotiate the status of the offshore islands; the administration's deliberations surroundding the possibility of U.S. food aid for Communist China; and the growing trend advocating a more flexible American approach toward Peking and the circumstances that militated against the development of such ideas. Rather than pursue alternative approaches, however, the Kennedy administration chose to perpetuate the status quo in the U.S., thus maintaining its posture toward both Chinese governments as well as the tenuous balance of power in East Asia. Despite the lack of a major departure from existing policies, initiatives proposing a reappraisal of U.S. China policy during the Kennedy administration precipitated discussions and debates that significantly contributed to the eventual transformation of Sino-American relations.

From the outset of the Kennedy administration speculation arose, both domestically and internationally, regarding the potential need for change in U.S. China policy, including the possible re-examination of U.S. support of the Republic of China and the containment policy against Communist China. One issue that required the immediate attention of the new administration was the Chinese representation matter at the UN. With indications of waning international support for the moratorium procedure, which delayed discussion of the Chinese representation issue to the following General Assembly session, Kennedy's foreign policy advisers realized the need to re-evaluate not only the circumstances involved at the UN but also the fundamental aspects of the new administration's posture toward the two Chinese governments. Although the United States' support of the Chinese Nationalists was best manifested in its staunch support of the GRC as the sole representative of the Chinese people at the United Nations, the practicality of continuing such support for the GRC was brought into question as Presidential advisers began preparations 
for the $16^{\text {th }}$ Session of the General Assembly in 1961. It became increasingly evident that the yearly request for a moratorium to delay discussion of the issue until the next General Assembly session would be difficult to obtain. For nearly ten years since the Sixth Session of the Assembly in 1951, use of the moratorium regarding the Chinese representation question had been a U.S.-supported approach in reaction to Peking's threat to the "peace-loving" and "law-abiding" countries of the free world. Due to the revolutionary and militant character manifested in its international behavior, the Chinese Communists were consistently refused consideration as appropriate candidates to represent the Chinese people in an international body that promoted international peace. However, it became increasingly difficult to deny that the People's Republic of China retained firm control over the mainland and governed the lives of over 600,000,000 Chinese people. Prompted by indications of probable defeat of the moratorium formula and a growing consensus within the international community for the inclusion of Communist China, the Kennedy administration was forced to investigate a new approach to the Chinese representation matter at the United Nations. With the recent addition of new members from the newly-independent African and Asian states to the General Assembly and changes to policy positions of several governments within the international body, the administration needed to reconsider U.S.-China relations vis-à-vis emerging realities of the increased visibility and recognition of Communist China.

\section{UN MEMBERSHIP FOR OUTER MONGOLIA}

By late June 1961, the question of UN membership for Outer Mongolia became a central issue between the United States and the Republic of China, and tensions also escalated surrounding the Chinese representation question. The GRC maintained its position that it would veto any proposal of membership for Outer Mongolia, despite the severe consequences that would inevitably result in a veto of the Soviet-sponsored bid. The Soviet Union also made it clear that if the GRC vetoed the membership proposal of Outer Mongolia, it would in turn deny admission of the African state of Mauritania. This denial would then prompt 11African states, supporting the admission of Mauritania, to vote against the Republic of China in any membership-related question. With increasing signs of international support for the inclusion of Communist China, the United States could not jeopardize 11 African votes, and therefore, needed to convince the GRC to refrain from using its veto against Outer Mongolia.

Meanwhile, formal recognition of Outer Mongolia became a serious consideration for the Kennedy administration. Chester A. Bowles, the Under Secretary of State, along with others in Washington, advocated that significant political advantages could be reaped from a formal recognition of Mongolia. By recogni- 
zing Outer Mongolia, which subscribed to Soviet-style communism, it could be demonstrated to the world that the U.S. was able to distinguish "between the aggressive, Stalinist policies of Communist China and the more moderate Soviet policy under Khrushchev." "In addition, an embassy in Outer Mongolia would allow the U.S. to have a foothold in a strategically located area, having unprecedented access to both the Soviet Union and Communist China. The State Department further investigated whether Outer Mongolia would be receptive to an exchange of ambassadors by sending feelers to the Mongolian Ambassador in Moscow. It was clear that under conducive circumstances, Washington was interested in establishing formal relations with Outer Mongolia.

By the end of June 1961, the main point of contention for the GRC revolved around the predisposition of the U.S. toward Outer Mongolia and the perceived American support for the latter's entry into the UN. This sensitive topic for the GRC would become a major obstacle in U.S.-GRC relations, precluding effective dialogue regarding the strategies to be used at the next UN session. In a meeting with Assistant Secretary for Far Eastern Affairs, Walter P. McConaughy, on June 29, and the GRC Ambassador, George K.C. Yeh, inquired about the U.S. position regarding Outer Mongolia. ${ }^{2}$ McConaughy explained that while the U.S. did not expect the GRC to support or vote for Outer Mongolia at the United Nations, the U.S. would not join forces with the GRC to oppose the Outer Mongolian bid for UN membership. Since the Soviet Union had linked the admission of Outer Mongolia with that of Mauritania, crucial African votes were at stake if either the GRC or the U.S. prevented the admission of Outer Mongolia to the UN. The Assistant Secretary emphasized that neither the U.S. nor the GRC could "afford to antagonize the African states which feel very strongly about Mauritania's admission to the United Nations."

However, the progress of potential U.S. recognition of Mongolia was suspended by the strong reactions of the GRC and the U.S. Congress. To Chiang Kaishek and his government, U.S. initiations toward Outer Mongolia signaled an alarming shift in relations between the United States and the communist world. Suspicions arose throughout Taiwan that the Kennedy administration appeared to be increasingly influenced by the pressures of communism. The GRC believed that if the U.S. recognized Outer Mongolia, the next step would be the recognition of Communist China. Although the GRC's confidence in its U.S. ally was shaken, Kennedy reminded Chiang that the question of Outer Mongolia's admission to the $\mathrm{UN}$, which was directly linked to the outcome of the Chinese representation issue, remained a battle that required a joint strategy by both the U.S. and the GRC:

... the cold, hard fact is that the French African states have accepted the Soviet linking of the Mauritanian and Outer Mongolian applications as a matter of practical power politics and have made the GRC and U.S. vote 
on the Outer Mongolian application the touchstone of their subsequent vote on Chinese representation. ${ }^{4}$

Despite American pleas, however, the GRC continued to resist Outer Mongolia's admission to the UN. The GRC remained firm that it would abstain from the Outer Mongolian bid for UN membership only if there were sufficient other abstentions to ensure that the latter remained excluded from the UN. Otherwise, the GRC maintained that it would exercise its veto against the application. According to Chiang, to allow the admission of Outer Mongolia to the United Nations was tantamount to succumbing to Soviet blackmail and would be a signal of defeat for all of East Asia in its struggle against communism. ${ }^{5}$

From Taipei, Ambassador Drumright addressed his concerns to the State Department regarding the obvious deterioration of U.S.-GRC relations. In a private meeting, Chiang Kai-shek made it clear to Drumright that the U.S. position on Outer Mongolia and the Chinese representation issue was "incompatible with consideration due a close ally." In fact, the Generalissimo added that the State Department either "misunderstood, miscalculated or ignored the GRC's position on these vital issues." Chiang asserted that the GRC was tired of being "kicked around" in the UN and that there was little incentive to remain a member of the organization. If U.S. support were to be withdrawn, which would be evidenced through the support of Outer Mongolia or the support of a "two Chinas" solution, Chiang concluded that there was no advantage gained by remaining in the UN "only to become a 'victim' of power politics."

In terms of the Chinese representation issue, the Generalissimo stated that the GRC had not refused to consider alternative approaches to the moratorium. However, Chiang remained adamant that any formula implying a "two Chinas" arrangement would be opposed by the GRC, and that his government would withdraw from the UN rather than accept such an arrangement. Drumright was convinced that the GRC would withdraw "without the slightest hesitation" if the "successor states" or recognition of a "two Chinas" formula was approved, and that further attempts by the U.S. to persuade the GRC would only harden the Generalissimo's determination to leave the UN. The U.S. Ambassador concluded that Chiang appeared resolute in his decision not to accept compromises perceived to be out of line with the fundamental policies of the GRC. If the U.S. pursued actions which were contrary to GRC beliefs, whether on the Outer Mongolia or the Chinese representation issue, Chiang warned that he would regard them as "unfriendly acts" and that such action would confirm his suspicions of changes in U.S. policy. ${ }^{7}$ From a tactical standpoint, Drumright believed that U.S. collaboration with the GRC on the China representation issue would become virtually impossible if the administration proceeded to establish relations with Outer Mongolia and support its admission to the UN. 


\section{GRC'S VICE PRESIDENTIALVISIT TO WASHINGTON}

On July 28, 1961, days before the official visit by Vice President Chen Cheng of the Republic of China, Kennedy and his advisers met to discuss the Chinese representation matter and the question of UN membership for Outer Mongolia. From the outset, the effects of the GRC's resolute position opposing any "two Chinas" approach were evident as the Secretary of State Dean Rusk clearly steered the focus toward adopting the "important question" procedure at the next UN session. ${ }^{8}$ Rusk stated that as any "two Chinas" proposal remained unacceptable to the GRC, the "important question" tactic needed to be pursued at the coming General Assembly session since the approach offered a "reasonable chance" of getting the necessary blocking, with one third of votes, to prevent any significant changes relating to the Chinese representation matter. Meanwhile, Kennedy was apprehensive of solely using the "important question" tactic; he thought that it would appear "too transparent a blocking measure" when examined by other countries. The President thus inquired about the Swedish proposal that called for a commission to study the problem and report back to the $17^{\text {th }}$ General Assembly. Harlan J. Cleveland, Assistant Secretary of State for International Organization Affairs, noted, however, that the Chinese Nationalists were "allergic" to the Swedish proposal, due to the GRC's fears about the composition of such a commission. Rusk agreed with the GRC sentiment, adding that a study commission would likely recommend "some sort of two Chinas solution." Kennedy suggested that some variant of the Swedish proposal, which would be acceptable to the GRC, be investigated, as he believed it was important to formulate a "more attractive proposal" that indicated a moving toward a final solution of the Chinese representation issue. The President reminded his advisers, "we must do what we have to in order to win" at the coming UN session, stressing the importance of convincing the Chinese Nationalists that the common objective was to keep Communist China out of the UN. It was clear that at least for the first year of his Presidency, Kennedy did not want to damage solid U.S.-GRC relations with fundamental changes to U.S. China policy. At the same time, however, it was also evident that he understood changes to the China policy would eventually have to be made due to international pressure.

Kennedy was informed by the State Department that several countries that had previously voted against the entry of Communist China recently indicated a change in position. It was noted that although Pakistan had not voted against the U.S. and GRC the previous year due to a special plea by President Eisenhower, it had been made clear by the Pakistanis that the previous year would be the last time they would accede to a U.S. request. And although Nigeria was friendly to the United States, it was known that the former would vote against the U.S., in accordance with the general Commonwealth position. It was also mentioned that 
Brazil appeared to have had a change of attitude regarding the Chinese representation issue. With the growing number of countries unsatisfied with the prevailing circumstances surrounding the Chinese representation matter, the United States and the GRC needed to join forces in an effective strategy to realize their objectives at the UN.

By mid-1961, the Kennedy administration was forced to re-evaluate U.S.GRC relations as a growing number of policy makers appeared to be increasingly interested in a more pragmatic and long-term approach toward the Republic of China, stemming from complications regarding UN tactics. A comprehensive assessment of the U.S. China policy was considered necessary by the administration in an effort to effectively deal with "the realities of life in the 1960s."

... the U.S. will not in fact be able to pursue the same China policy during the Sixties as its predecessor did. We have been highly successful in postponing for a decade many of the logical consequences of the Communist takeover of the mainland China. But few would argue that we will be able to do so much longer (a crucial test will come this year in the UNGA). The eroding international position of the GRC along with the rise of Peiping's star, makes it less and less possible to uphold in the UN the fiction that the GRC represents "China.",

To recognize the GRC as the sole government representing the whole of China appeared increasingly unrealistic, while the old policy of containing Chinese Communist power by a simple policy of non-recognition was believed to be ineffective by those in the administration advocating change in the U.S. China policy.

On July 31, President Kennedy and his advisers met with the GRC Vice President General Chen Cheng and other high officials representing Nationalist China. From the outset, Kennedy emphasized that a main objective in United States policy with regard to the Chinese representation question was to take all available means to prevent the Chinese Communists from entering the United Nations. ${ }^{11}$ The President asserted that the matter at hand was how to get a majority vote in the General Assembly. ${ }^{12}$ The Chinese representation question would be won or lost in a very close vote, and it was hoped that the U.S. and the GRC would not be defeated at the UN by a few votes. At a point where the GRC's confidence in the U.S. was visibly shaken, Kennedy deliberately avoided further irritation to U.S.-GRC relations and instead emphasized that the United States would not abandon its ally and would resist international pressures which insisted that a more realistic approach be taken toward Communist China at the UN. The task that remained, however, was to convince the GRC of needed measures that would ensure their continued status at the UN while preventing the entry of the Chinese Communists. 
On the topic of potential U.S. relations with Outer Mongolia, Rusk assumed a conciliatory posture with GRC officials, as he explained that the situation was one of "great flexibility" and that the U.S. was "in no rush for bilateral relations.", The Secretary's statements were of a decidedly different nature from those relayed earlier to the GRC by the State Department. Although previously, U.S. officials had taken the attitude that decisions regarding relations with Outer Mongolia would be based purely on U.S. national interests, Rusk deferred such a posture to the potentially negative effect Outer Mongolia could have on the Chinese representation question at the UN. The immediate problem involving Outer Mongolia, Rusk added, was that the entire African community was "terribly troubled" over the question of UN membership for Mauritania. The Secretary informed the GRC officials that the Soviet Union's linking of Mauritania and Outer Mongolia involved approximately 10 to 15 votes on Chinese representation. Despite the repeated warnings regarding the wavering of important African votes, however, Vice President Chen Cheng showed no sign of change in his government's position, stating that in a meeting prior to his departure for Washington, the representatives of the major branches of the government concluded unanimously that the GRC "must use all means under the United Nations Charter to block Outer Mongolia's entry into the United Nations." "14 The gamble was one that the GRC would take to the brink, risking both its UN membership and international status.

\section{CONTINUED PRESSURES ON THE GRC}

On August 5, 1961, at Hyannis Port, Kennedy emphasized to UN Ambassador Stevenson that his determination that the United States not be defeated on the issue of Chinese representation at the UN. At the same time, however, the President wanted to avoid taking "any major step" this year, although he realized that the study committee approach or "any other means of postponement" might only lead, as early as the following year, to the inevitable "two Chinas proposal or even to ChiCom admission in some form." "15 Kennedy's politically motivated short-term focus regarding the Chinese representation issue was to ensure that the GRC retain its position at the UN, at least for the coming year. A defeat on the China question in the form of the Chinese Communists replacing the GRC would assuredly arouse public and Congressional scrutiny of the new administration. Therefore, Kennedy was convinced that the United States should continue in its efforts to persuade Chiang and his government that in the interests of protecting the GRC's UN position, the latter needed to refrain from using its veto on Outer Mongolia's UN membership vote. In terms of the U.S. vote, Kennedy noted that the United States could not exclude the option of voting for the Outer Mongolia application if it could be assured that by doing so, the French Africans would vote in favor of the U.S. position on the China question. It could not be forgotten that a defeat on the 
Chinese representation matter would not only jeopardize the GRC's international standing, but more importantly, it would significantly damage the prestige of the United States and the new administration.

In an August 15 letter to Chiang Kai-shek, Kennedy urged the Generalissimo to refrain from voting against Outer Mongolia's admission to the UN. Referring to the joint communiqué issued at the conclusion of Vice President Chen's Washington visit, Kennedy reinforced the importance of continued collaboration in the struggle against communism.

The joint communiqué issued by Vice President Chen and me following our discussions pointed out our mutual awareness of the world-wide nature of the Communist threat and of the belligerency and hostility of the Communist threat and of the belligerency and hostility displayed by the Communists in areas such as Berlin, Laos, Korea and Viet-Nam. I am sure you will agree with me that the increasingly grave nature of the Communist challenge makes it imperative for all of us in the free world to maintain our solidarity and not allow the forces of Communism to divide and thereby undermine our joint strength. ${ }^{16}$

The President reminded Chiang that the most careful studies indicated that if Mauritania were denied entry into the UN due to a veto against Outer Mongolia's membership, the French African states would retaliate by voting against the GRC in the Chinese representation issue. ${ }^{17}$ In such a situation, despite the best efforts of the United States, the likely outcome would entail the unseating of the GRC and a subsequent replacement by the Chinese Communists. The adverse effects of Outer Mongolia's admission were thought to be insignificant compared to the potential outcome of the Chinese Communists entry into the UN.

The GRC's security interests were also believed to be in jeopardy if the Chinese Nationalists were to lose their UN position. Kennedy warned Chiang that in such a situation, the United States would have difficulty gathering free world support for military action in defense of the Republic of China. ${ }^{18}$ Necessary free world support for the GRC in political, diplomatic and economic matters would also be exceedingly difficult to obtain in a situation where free world sympathies were increasingly dissipating and where the GRC's international position was undercut. In addition, the GRC's departure from the UN would inevitably lead to increasing isolation as countries began switching their recognition to Communist China. Consequently, it would be difficult to maintain solid support against Communist China's pressures against the GRC. Moreover, there would be a real danger that the United States would itself become more isolated in its support of the GRC against Communist China. Thus, it was advised that the GRC not ignore the potentially serious damage that could result to its own national security and to 
U.S. interests from the GRC's refusal to engage in strategies that would secure its UN membership.

Despite the potential for undesirable outcomes if the GRC persisted in its position, Chiang Kai-shek responded to Kennedy's letter by reinforcing his government's position and adamant belief that the United States had the influence within the United Nations to make certain that Outer Mongolia be denied membership. ${ }^{19}$ It was believed in Taiwan that as a leader in Asia, the United States should possess the motivation and necessary influence within international circles to preclude the use of the veto by the GRC.

[Under] the circumstances the question of Outer Mongolia's application for UN membership could best be dealt with by creating a situation in which the Republic of China would not be forced to exercise the veto when the matter comes up in the Security Council. And such a situation can be obtained if the United States should so use its direct and indirect influence that Outer Mongolia will not get the necessary minimum of seven votes. In view of the United States' determination to help maintain our position, and in view of the considerable influence your country commands in the United Nations, it should be possible for our two countries to attain our common objective by following a plan of action to be agreed upon by our two countries after careful consultation. ${ }^{20}$

Thus, the Outer Mongolian issue became one that was left for the United States to solve, as Chiang's statements clearly demonstrated the GRC's dependence on the United States. If indeed the United States' commitment to keep the Chinese Communists out of the UN was genuine, then Chiang believed that the U.S. could then somehow use its power and influence in the UN to persuade the questionable African states in the vote on Chinese representation. In case the United States could not acquire the necessary seven votes, the GRC would make it appear that the Chinese had no choice but to use its veto.

By late August, it appeared to Washington that the French African states were determined to defend Mauritania as they made clear that their UN votes would be swayed by whether the latter gained membership in the organization. In an outgoing telegram from the State Department, select consular posts were informed that French UN representative, Armand Bérard, confirmed that the French Africans would vote against the U.S. and its supporters on the Chinese representation issue, including the "important question" proposal, in retaliation if the GRC used its veto against Outer Mongolia. ${ }^{21}$ However, if Outer Mongolia was not vetoed and Mauritania was admitted, Bérard believed that the French African states, with the exception of Senegal, would "go along with U.S. on this question." In terms of whether the French African states would support the U.S. on the "important 
question" proposal if the U.S. voted for Outer Mongolia rather than abstaining in the face of a GRC veto, Bérard was doubtful that the U.S. would be able to acquire the needed votes from the French African states. Therefore, if the United States could not convince the GRC to refrain from using its veto on Outer Mongolia's membership vote, the Chinese representation issue would most likely be defeated, resulting in the removal of the GRC and the seating of Communist China at the UN.

With discouraging prospects and time running out, concrete decisions needed to be made by the Kennedy administration regarding the U.S. position on the Chinese representation issue and the tactics to be used at the coming UN session. In a White House meeting, Kennedy and his top aides discussed what would be necessary to avoid defeat on the China question. Assistant Secretary Cleveland, who drafted the memorandum of action taken at the September 5 meeting, wrote that at the meeting Kennedy was posed with two major policy questions:

(i) Do you believe that Ambassador Stevenson should now be authorized to make it known informally to other delegations that the United States does not preclude the possibility that a General Assembly study committee would recommend for the consideration of the General Assembly at its 1962 session an essentially "two Chinas" solution based on the successor states approach? and,

(ii) Are you prepared to authorize Ambassador Stevenson to vote affirmatively in the Security Council on the application for UN membership of the Mongolian People's Republic, if in his judgment such a vote will substantially assist him in developing support among the French African states for the U.S. position of Chinese Representation? ${ }^{22}$

The President answered affirmatively to both questions, stressing the importance of keeping the Chinese Communists out of the United Nations for at least the coming year. At this juncture, it appeared that virtually any reasonable strategy which could ensure that the United States would not be defeated on the Chinese representation question at the coming session of the UN would be seriously considered by the Kennedy administration, even the possibility of having to adopt a "two Chinas" situation as early as the following year. Rusk reported that the State Department had conducted exploratory talks with other countries regarding a two-pronged approach to the Chinese representation matter: a resolution that combined declaring that any changes to China's representation constituted an "important question" in addition to the establishment by the General Assembly of a study committee to consider criteria for UN membership and related problems. Preliminary consultations with other countries indicated that there could be "no certainty of obtaining the required majority for either proposal." 23 Consequently, it was proposed by the State Department that a "sweetener" be added to the approach by 
proposing to set up an Assembly committee to study the possibility of enlarging the Security Council and the Economic and Social Council. ${ }^{24}$ The overall effect was to be the delaying of a decision on the Chinese question for at least the coming year. The State Department's findings were particularly worrisome to Kennedy and his advisers who remained determined not to be defeated on a major issue such as China's representation at the UN.

In early September 1961, Kennedy wrote to Chiang Kai-shek in a last attempt effort to convince the Generalissimo to refrain from using the veto on the Outer Mongolian application in order to safeguard the GRC seat at the United Nations. ${ }^{25}$ In addition, as the GRC's discontent with the State Department was becoming increasingly evident, it was hoped by the President's advisers that Kennedy's letter would demonstrate the President's support of the recommendations emanating from the State Department. Kennedy's letter also reinforced that since the Chinese representation matter was one of "such vital importance to the United States," if the two governments were unable to come to an agreement, the United States would claim its right to "pursue whichever avenue we consider best calculated to advance the objective which we both seek." The United States could not merely watch the GRC seriously jeopardize its position at the UN and then be left to deal with the consequences of defeat.

By mid-September, U.S. officials consolidated their views and constructed a course of action that reflected the administration's determination to avoid, in the short-term, defeat on the Chinese representation matter. The standing instructions outlined to UN representative Stevenson included taking the initiative to introduce the "important question" approach at the General Assembly if other countries could not be induced to take the lead. ${ }^{26}$ Significantly, Stevenson was also authorized to vote in favor of Outer Mongolia's membership bid and to state that the United States did not "exclude the possibility that the study committee would recommend to the 1962 session a successor state solution," thus accepting the idea of a "two Chinas" solution. ${ }^{27}$ Although it was realized in Washington that the "successor states" proposal and a positive U.S. vote on Outer Mongolia would be vehemently opposed by the GRC, the instructions for Stevenson demonstrated that the United States was prepared to act independently of Nationalist China if an agreement in tactics could not be reached between the two governments.

\section{DETERIORATION OF U.S.-GRC RELATIONS}

Clearly, persistent disagreement on the tactics to be used regarding the question of Outer Mongolia's bid for UN membership had taken its toll on U.S.-GRC relations. In a telegram to the Secretary of State, the U.S. Ambassador to the Republic of China, Everett F. Drumright, reported that he was troubled by the GRC's mood of "deep gloom and dissatisfaction mixed with determination to go down 
with ship rather than compromise over Outer Mongolia and ChiRep issues" and the growing disillusionment with the United States. In a September 11 letter to Kennedy, Chiang Kai-shek maintained his prior convictions and insisted that to agree to UN membership for Outer Mongolia would be, in effect, yielding to "international blackmail" and that continued UN membership for the GRC would not compensate for it. ${ }^{28}$ With tensions running high at the State Department, Rusk could not easily dismiss the role of a crucial actor in U.S.-GRC relations and expected Drumright to be more forceful in pressuring Chiang and his government towards a posture which would not jeopardize the entire Chinese representation question for both the GRC and the United States. Aware of Drumright's sympathetic posture toward the Chinese Nationalists, Rusk reminded the Ambassador that what was expected was "frank and accurate reporting from Ambassadors on attitude host government but such a reporting in turn becomes point of departure for maximum effort Embassy as well as Dept. to search for means for giving effect to U.S. policy." 29 The Secretary wanted it reinforced that if the GRC chose to "go down with ship" rather than compromise on the Outer Mongolian issue, the United States would not share responsibility for the outcome and would "make it quite clear if necessary that the GRC elected to commit political suicide in the UN despite our best efforts." Not only was the State Department prepared to protect the United States' international image, it was considered politically essential to set the record straight in the case of a potential domestic crisis if the GRC lost the China seat to the Chinese Communists. The Secretary added that the President as well as the State Department had spent "enormous effort to mobilize international support for the GRC," as the Chinese representation issue had been one of the "principal topics of conversation" with a host of foreign officials in the past several months. Urging Ambassador Drumright to make the gravity of its situation clear to the GRC, the Secretary concluded that while the United States still hoped to give the Chinese Nationalists the "strongest possible support because of fundamental common interests," in the Chinese representation matter, cooperation would be required from the GRC.

In Taipei on October 2, Ambassador Drumright met with Chiang Kai-shek and urged the Generalissimo to reconsider the GRC's position. ${ }^{30}$ Drumright emphasized that U.S. policy regarding Outer Mongolia was aimed at furthering the mutual interests of the United States and the GRC. Upon listing seven questions, mostly dealing with the position and attitude assumed by the United States with regard to Outer Mongolia, Chiang stated that if he could receive "satisfactory answers" to the questions, the GRC might be prepared to review its position toward the Outer Mongolia problem. ${ }^{31}$ Chiang's comments were the first indications of potential accommodation in the GRC's posture and a reluctant acquiescence to cooperate with the United States. Chiang added that exercising the GRC's veto was "not relished" and that if there were other possibilities then his government 
was ready to consider them jointly with the United States. However, the Generalissimo also added that "[i]f present U.S. attitude should persist," the possibility of cooperation between the two countries would be removed. Ambassador Drumright explained to the State Department that Chiang was referring to what was regarded as "unjustifiable pressures placed on GRC in recent days to modify its position on OM (Outer Mongolia) admission to UN." ${ }^{, 32}$ More specifically, the Ambassador indicated that State Department pressures and handling of the problem had not been agreeable and had engendered "a seriously adverse reaction" within the GRC.

From this point, National Security Adviser McGeorge Bundy drafted a message to be sent to Chiang Kai-shek from Kennedy that focused on the mutuality of interests between the two governments. It was to be suggested by the President that if the GRC avoided using its veto, the United States would then discontinue any new initiatives toward Outer Mongolia under existing circumstances. Joint efforts by both the GRC and the U.S. were considered essential in advancing the "common needs of the free people" and would allow increased effectiveness in mutual interests. The personalized message from Kennedy was sent with hopes that Chiang would ultimately change the GRC position on Outer Mongolia.

Kennedy's message was successful in pushing the GRC further towards accommodation as the Generalissimo relayed his appreciation for messages from both the President and Bundy which had demonstrated to Chiang a strong desire to reach a common understanding between the two governments. However, the immediate response by the U.S. also indicated to Chiang that Washington might be willing to negotiate the conditions under which a potential shift in the GRC posture could occur. Chiang informed Ambassador Drumright that before his government could commit to any agreements regarding the Outer Mongolian membership question, a public statement of U.S. support by President Kennedy and a promise that the United States would use all means, including Security Council action, if necessary, to block the admission of Communist China would be required. ${ }^{33} \mathrm{He}$ added that if the U.S. could provide the necessary public statements of support, then, he could potentially persuade the Legislative Yuan and the public to forego the veto on Outer Mongolia. In a memorandum to the State Department, Drumright added his impression that Chiang "desperately wants statement from President Kennedy on which he can pin his defense of volte face." The Generalissimo had stated that only "a fresh statement from President Kennedy would suffice for his purposes." The Ambassador sensed that if a message from Kennedy was not forthcoming, Chiang would most likely refrain from any concessions regarding Chinese representation at the UN. The GRC's leader needed reassurances that if Outer Mongolia were to obtain membership to the UN at the coming session Communist China would not be the next to follow. Confident that the Kennedy administration wanted to avoid defeat on the Chinese representation matter almost as much as the GRC hoped to maintain its UN position, Chiang 
maneuvered the GRC's position to one linked to the public responses by the United States.

The following day the State Department instructed Drumright to inform Chiang of the President's plan to reinforce at his forthcoming October 11 press conference that the United States remained "strongly opposed" to the entry of Communist China into the United Nations and would continue to give its strong support to the representation of the Republic of China in all UN bodies. ${ }^{34}$ In terms of Chiang's specific request for a public statement that the United States would use its veto, if necessary, to block the admission of Communist China, it was considered "damaging" to both governments' common position in the UN. The Kennedy administration wanted to avoid any guarantees regarding the use of its veto against Communist China. Drumright was to relay that as the United States had already begun to rally support from the French African states on the basis of GRC cooperation with regard to Outer Mongolia, reasserting the use of its veto by the GRC would be sure to result in yet a higher price to both the Chinese Nationalists and the United States. The following day, October 8, the GRC's Acting Foreign Minister informed Drumright that he believed Kennedy's message would not be sufficient to appease Chiang. ${ }^{35}$

\section{THE SECRET AGREEMENT: KENNEDY'S PRIVATE ASSURANCES TO CHIANG}

With indications that Chiang faced overwhelming domestic reaction to a potential change in the GRC position vis-à-vis Outer Mongolia at the UN, Bundy informed the Chief of the Central Intelligence Agency Station in Taipei, Ray S. Cline, in a top-secret message that Kennedy was prepared to give a "private reassurance" to the Generalissimo, which would establish that "if at any time a U.S. veto is what will be effective in preventing Chinese Communist entry into the UN, the United States will use that veto." 36 Cline was to make it understood by Chiang that the President's assurance was to be kept "wholly private for the powerful reason that public disclosure of such a U.S. pledge at this time would be deeply damaging to the common cause at the UN." It was cautioned, however, that "there should be no leak" and that the United States would "have to deny any rumors about reassurance on the veto" in order to protect its position at the UN. ${ }^{37}$

After an initial agreement had been reached between Chiang and Kennedy, the Generalissimo suggested that the President's private assurances be delivered orally by Ambassador Drumright as a diplomatic message. ${ }^{38}$ Chiang did not want the private assurance to be in a written form because "in China this would imply lack of trust between two correspondents." The following day, Drumright met with Chiang and relayed Kennedy's private assurance that "if at any time a U.S. veto is necessary and will be effective in preventing Chinese Communist entry into the 
UN, the U.S. will use that veto." 39 Chiang stated that he would "be obliged to reveal assurances in greatest confidence to a few high trusted officials" as the Generalissimo considered it essential to gain support for a change in the GRC's position regarding Outer Mongolia. Drumright reminded Chiang that the U.S. would have to issue a denial if any word of the President's assurance to the Generalissimo was leaked. As had been agreed upon between Cline and Chiang Kai-shek's son, Chiang Ching-kuo, the GRC would not reverse its position vis-àvis Outer Mongolia until after Kennedy's press conference on October 18. The Kennedy administration, thus, successfully persuaded the GRC's leader in the final hour to reverse the government's position on Outer Mongolia to one that would not procure the wrath of the African states whose votes were crucial to maintaining the Republic of China's position at the UN.

On October 24, Kennedy received a letter from Chiang Kai-shek on the eve of the vote regarding Outer Mongolia's bid for UN membership. ${ }^{40}$ Chiang declared that the public statement made by President Kennedy, which reaffirmed U.S. support for the GRC in the United Nations and continued opposition against Communist China's admission, was "timely and re-assuring." ${ }^{41}$ Chiang added that it was only that afternoon the Chinese Government had been able to obtain the endorsement of the Legislative Yuan regarding the decision to continue opposing Outer Mongolia's admission without the use of the veto. ${ }^{42}$ On October 25, the United Nations Security Council recommended the Mongolian People's Republic for admission to the United Nations by a vote of 9-0, with one abstention (the United States). ${ }^{43}$ Outer Mongolia was admitted to the United Nations by General Assembly Resolution 1630 on October 27, 1961. The Republic of China did not participate in the voting procedure.

Although major change to the Chinese representation matter was narrowly averted, the various alternatives to the moratorium approach debated throughout 1961 demonstrated the administration's inclination towards a future "two Chinas" resolution. In addition, it was becoming increasingly evident to the Kennedy administration that the growing demands of the other nations to include Communist China in the international community would need to be addressed by the United States in the near future.

\section{CONCLUSION}

On December 1, 1961, UN Ambassador Adlai Stevenson delivered a State Department-drafted speech to the General Assembly, dealing solely with the issue of Chinese representation. He asserted that the United Nations would be making a "tragic and perhaps irreparable mistake" if it were to yield to Communist China's claim to replace the Republic of China in the United Nations. ${ }^{44}$ Stevenson argued that if the PRC were granted admission into the UN, the Peking regime would be 
encouraged by the success of its "bitter words and ruthless actions" and gain momentum to be all the more forceful and disruptive within the community of nations. The UN Ambassador made it clear that admission of the PRC would violate and defy the basic principles of the UN Charter. At a minimum, the people of the United States would lose its confidence in the UN, and this fact alone was thought to be significantly detrimental to the organization. ${ }^{45}$

On December 15, the Soviet draft resolution to admit Communist China to the United Nations was defeated by a vote of 48 against, 37 for, and 19 abstentions. ${ }^{46}$ The considerable margin was explained by Soviet insistence that Communist China's admission be accompanied by Taiwan's expulsion. ${ }^{47}$ On the same day, the General Assembly voted 61 to 34 with 7 abstentions to make the Chinese representation an "important question," requiring a two-thirds majority of the Assembly to pass proposals for change. In terms of the Chinese representation question, the UN outcome in 1961 was considered a success by the Kennedy administration. The "important question" approach afforded Kennedy's policy advisers, at a minimum, another year to formulate strategies to ensure continued GRC representation of China at the UN. The lessons of 1961, however, would not be soon forgotten by the administration. Although Kennedy and his advisers maintained U.S. support of the GRC due to Congressional and public pressures, the increased international demand for the inclusion and recognition of the PRC would become a looming presence in considerations of future U.S. China policy.

\section{REFERENCES}

Acheson, Dean. 1958. Power and Diplomacy. Cambridge, Harvard University Press. Bachrack, Stanley D. 1976. The Committee of One Million: 'China Lobby'Politics, 1953-1971. New York, Columbia University Press.

Barnett, A. Doak. 1977. China and the Major Powers in Asia. Washington, D.C.

Barnett, A. Doak. 1961. Communist China and Asia: A Challenge to American Policy. New York, Vintage.

Blum, Robert. 1966. The United States and China in World Affairs. New York, McGraw-Hill.

Blum, Robert. 1966. U.S. Policy Towards Communist China - The Alternatives. In Foreign Policy Association, The Headline Series. Edited by A. Doak Barnett, No. 180.

Bowles, Chester A. 1971. Promises to Keep: My Years in Public Life, 1941-1969. New York, Harper and Row.

Bowles, Chester A. 1960. The 'China Problem' Reconsidered. Foreign Affairs.

Chang, Hsin-hai. 1965. America and China: A New Approach to Asia. New York, Simon and Schuster.

Cohen, Jerome A. et al. eds. 1971. Taiwan and American Foreign Policy: The 
Dilemma in U.S.-China Relations. New York, Praeger.

Cohen, Warren I. 1990. America's Response to China: An Interpretative History of

Sino-American Relations. 3d ed. New York, Wiley.

Congressional Quarterly Service, ed. 1967. China and U.S. Far East Policy, 19451967. Washington, D.C.

Dean, Robert D. 1998. Masculinity as Ideology: John F. Kennedy and the Domestic Politics of Foreign Policy. Diplomatic History 22(1).

Dulles, Foster Thea. 1972. American Policy Toward Communist China, 1949-1969. New York, Crowell.

Fairbank, John K., Edwin O. Reischauer and Albert Craig. 1965. East Asia: The Modern Transformation. Boston, Houghton Mifflin.

Fairbank, John K., Edwin O. Reischauer and Albert Craig. 1967. China: The People's Middle Kingdom and the U.S.A. Cambridge, Harvard University Press.

Fairbank, John K., Edwin O. Reischauer and Albert Craig. ed. 1968. The Chinese World Order. Cambridge, Harvard University Press.

Fairbank, John K., Edwin O. Reischauer and Albert Craig. 1971. The United States and China. Cambridge, Harvard University Press.

Fetzer, James. 1989. Clinging to Containment: China Policy. Kennedy's Quest for Victory, American Foreign Policy, 1961-1963. Thomas G. Paterson, ed. New York, Oxford University Press.

Foot, Rosemary. 1995. The Practice of Power: U.S. Relations with China Since 1949. Oxford: Clarendon Press.

Friedman, Edward and Mark Selden, eds. 1971. America's Asia. New York, Pantheon.

Gittings, John. 1969. The Great Power Triangle and Chinese Foreign Policy. China Quarterly.

Hilsman, Roger. 1967. To Move a Nation: The Politics of Foreign Policy in the Administration of John F. Kennedy. New York, Doubleday.

Hinton, Harold, ed. 1987. Government and Politics in Revolutionary China: Selected Documents, 1948-1979. Wilmington, Scholarly Resources.

Hornbeck, Stanley K. 1955. "Which Chinese: Diplomatic Recognition and Official Representation." Foreign Affairs.

Iriye, Akira. 1967. Across the Pacific. New York, Harcourt, Brace and World.

Iriye, Akira. 1963. Dilemmas of American Policy Toward Formosa. China Quarterly.

Iriye, Akira. 1974. The Cold War in Asia. Englewood Cliffs, Prentice-Hall.

Kaufman, Burton I. 1993. John F. Kennedy as World Leader. Diplomatic History 17(3).

Kesaris, Paul, ed. 1982. CIA Research Reports: China, 1946-1976. Frederick, Md., Microfilm.

Kusnitz, Leonard A. 1984. Public Opinion and Foreign Policy: America's China Policy, 1949-1979. Westport, Greenwood. 
Lewis, John W. 1962. Quemoy and America China Policy. Asia Survey.

Lowenthal, Richard. 1961. Diplomacy and Revolution: The Dialectics of a Dispute. China Quarterly.

MacFarquhar, Roderick. 1972. Sino-American Relations, 1949-1971. New York, Praeger.

May, Ernest R. and James C. Thomson. 1972. American-East Asian Relations: A Survey. Cambridge, Harvard University Press.

Moorstein, Richard and Morton Abramowitz. 1971. Remaking China Policy: U.S.China Relations and Governmental Decisionmaking, Cambridge, Harvard University Press.

Paterson, Thomas G., ed. 1989. Kennedy's Quest for Victory: American Foreign Policy, 1961-1963. New York.

Rankin, Karl Lott. 1964. China Assignment. Seattle, University of Washington Press.

Rusk, Dean. 1990. As I Saw It. New York, W.W. Norton.

Schoenbaum, Thomas J. 1988. Waging Peace and War: Dean Rusk in the Truman, Kennedy, and Johnson Years. New York, Simon and Schuster.

Stevenson, Adlai. 1959. Putting First Things First. Foreign Affairs.

Thomson, James C., Jr. 1967. Dragon Under Glass: Time for a New China Policy. The Atlantic.

Thomson, James C., Jr. 1972. On the Making of U.S. China Policy, 1961-1969-A

Study in Bureaucratic Politics. The China Quarterly 50: 220-243.

Tucker, Nancy B. 1990. A House Divided: The United States, the Department of State, and China. The Great Powers in East Asia, 1953-1960. Warren I. Cohen and Akira Iriye, eds. New York, Columbia University Press.

Tucker, Nancy B. 1990. John Foster Dulles and the Taiwan Roots of the "Two Chinas' Policy. John Foster Dulles and the Diplomacy of the Cold War. Richard Immerman, ed. Princeton, Princeton University Press.

Tucker, Nancy B. 1983. Patterns in the Dust: Chinese-American Relations and the Recognition Controversy. New York, Columbia University Press.

United States. Department of State. 1960-1963. Bulletin. Washington, D.C.

United States. Department of State 1996. Foreign Relations of the United States:

Diplomatic Papers 1961-1963: Northeast Asia, Vol. XXII, Washington, D.C., United States Government Printing Office.

United States. Department of State 1964 Public Papers of the Presidents of the United States: John F. Kennedy 1961-1963. Washington, D.C., United States Government Printing Office.

Young, Kenneth. 1968. Negotiating with the Chinese Communists: The United States Experience, 1953-1967. New York, McGraw Hill. 


\section{ENDNOTES}

1 Roger Hilsman, To Move a Nation: The Politics of Foreign Policy in the Administration of John F. Kennedy (New York, 1967): 306.

2 Memorandum of Conversation, "Outer Mongolia and Chinese Representation," June 29, 1961. Department of State, Central Files, box 475, folder 303/6-2961. National Archives, College Park, MD.

3 Ibid.

${ }^{4}$ Letter to Chiang Kai-shek from John F. Kennedy, August 15, 1961. Presidential Office Files, folder 18, box 113a, JFKL.

5 Letter to John F. Kennedy from Chiang Kai-shek, August 26, 1961. Presidential Office Files, folder 18, box 113a, JFKL.

6 Telegram from the American Embassy in Taipei to the State Department, July 2, 1961. Department of State, Central Files, box 1309, folder 611.93/7-261. National Archives, College Park, MD.

7 Ibid.

8 Memorandum of Conversation, "Conference at White House on China Representation at United Nations and Outer Mongolia-United Nations Membership Application," July 28, 1961. Kennedy Library, National Security Files, Countries Series, China. Foreign Relations of the United States (Washington, D.C.: Government Printing Office, 1996), (hereafter FRUS) XXII: 99.

9 Ibid.

${ }^{10}$ Ibid.

${ }^{11}$ Memorandum of Conversation, "Chinese Representation in the United Nations," Department of State, July 31, 1961. National Security Files, box 22, JFKL.

${ }^{12}$ Ibid.

${ }^{13}$ Ibid

${ }^{14}$ Ibid.

${ }^{15}$ Memorandum of Conversation, "U.S. Strategy in the 16th General Assembly," August 5, 1961. Kennedy Library, Papers of Arthur Schlesinger, Jr., box WH22, Subject Files, UN Speeches, 8/3/ 61-8/11/61. FRUS XXII: 112.

${ }^{16}$ Letter to Chiang Kai-shek from John F. Kennedy, August 15, 1961. Presidential Office Files, folder 18, box 113a, JFKL.

${ }^{17}$ Ibid.

${ }^{18}$ Ibid.

${ }^{19}$ Letter, from Chiang Kai-shek to John F. Kennedy, August 26, 1961. Presidential Office Files, folder 18, box 113a, JFKL.

${ }^{20}$ Ibid.

${ }^{21}$ Telegram from the Department of State, August 31, 1961. Department of State, Central Files, box 476, folder 303/8-3161. National Archives, College Park, MD.

${ }^{22}$ Memorandum of Action, September 5, 1961. Department of State, Central Files, folder 301/9-661. FRUS XXII: 133.

${ }^{23}$ Memorandum from Dean Rusk to John F. Kennedy, September 5, 1961. Department of State, Central Files, folder 303/9-561. FRUS XXII: 134.

${ }^{24}$ Ibid.

${ }^{25}$ Telegram from the State Department to the Embassy in the Republic of China, September 6, 1961. Department of State, Central Files, 303/9-661. FRUS XXII: 134.

${ }^{26}$ Memorandum from Dean Rusk to Adlai E. Stevenson, "Representation of China in the United Nations," September 13, 1961. Kennedy Library, National Security Files, Countries Series, China. FRUS XXII: 135.

${ }^{27}$ Ibid.

${ }^{28}$ Telegram from Embassy in the Republic of China to the Department of State, September 11, 1961. Department of State, Central Files, 303/9-1161. FRUS XXII: 137, footnote No.1.

${ }^{29}$ Telegram from Department of State to Taipei, September 17, 1961. Department of State, Central Files, 303/9-1161. FRUS XXII: 137. 
${ }^{30}$ Telegram from Embassy in the Republic of China to the Department of State, October 2, 1961. Department of State, Central Files, box 1309, folder 611.93/10-261. National Archives, College Park, MD.

${ }^{31}$ Ibid.

${ }^{32}$ Ibid.

${ }^{33}$ Telegram from the Embassy in the Republic of China to the Department of State, October 4, 1961. Department of State, Central Files, 303/10-461. FRUS XXII: 146. Footnote 3.

${ }^{34}$ Telegram from the Department of State to the Embassy in the Republic of China, October 7, 1961. Department of State, Central Files, 303/10-661. FRUS XXII: 150.

${ }^{35}$ Telegram from the Embassy in the Republic of China to the Department of State, October 8, 1961. Department of State, Central Files, 303/10-861. FRUS XXII: 150.

${ }^{36}$ Message from McGeorge Bundy to Ray S. Cline, October 11, 1961. Kennedy Library, National Security Files, Countries Series, China General, CIA Cables 7/61-10/16/61. FRUS XXII: 154.

${ }^{37}$ Ibid.

${ }^{38}$ Ibid.

${ }^{39}$ Telegram from the Department of State to the Embassy in the Republic of China, October 16, 1961. Department of State Central Files, 303/10-1661. FRUS XXII: 160.

${ }^{40}$ Letter, from Chiang Kai-shek to John F. Kennedy, October 24, 1961. Presidential Office Files, folder 18, box 113a, JFKL.

${ }^{41}$ Ibid.

${ }^{42}$ Ibid.

${ }^{43}$ U.N.doc. S/4968; U.S. Department of State, Northeast Asia, 1961-1963, FRUS XXII: 161-162.

${ }^{44}$ Revised Draft Speech for Ambassador Stevenson, Chinese Representation, November 11, 1961. National Security Files, box 22, JFKL.

${ }^{45}$ Ibid.

${ }^{46}$ Hilsman, To Move a Nation: 310.

${ }^{47}$ Department of Central Intelligence Briefing, “Chinese UN Representation” December 18, 1961. National Security Files, box 22, JFKL. 